\title{
HUBUNGAN PENGKOORDINASIAN DENGAN PRESTASI KERJA KARYAWAN PADA CV. JAYA MOTOR DI LAMPUNG SELATAN
}

\author{
Siti Holisah ${ }^{(1)}$, Kuswarak $^{(2)}$, Sodirin ${ }^{(3)}$ \\ Fakultas Ekonomi Universitas Sang Bumi Ruwa Jurai \\ siti07.holisah@gmail.com,kuswarak@fe.saburai.ac.id, sodirin@fe.saburai.ac.id
}

\begin{abstract}
Abstrak. CV. Jaya Motor merupakan salah satu dealer kendaraan bermotor roda dua merk Yamaha yang berlokasi di Jalan Sidomulyo No. 45 Lampung Selatan. Perusahaan ini memasarkan berbagai jenis motor Yamaha seperti Jupiter Z, Yamaha Vixion, Yamaha Mio, Vega RR dan berbagai jenis yang lain. Permasalahan yang dihadapi adalah Apakah koordinasi mempunyai hubungan dengan prestasi kerja karyawan pada CV. Jaya Motor di Lampung Selatan. Tujuan penelitian adalah untuk mengetahui hubungan koordinasi terhadap prestasi kerja karyawan pada CV. Jaya Motor di Lampung Selatan. Metode penelitian yang digunakan adalah analisis kualitatif dan kuantitatif menggunakan rumus korelasi product moment. Teknik data yang digunakan adalah teknik populasi dari 27 orang karyawan. Hipotesis yang ajukan adalah "Ada hubungan pengkoordinasian dengan prestasi kerja karyawan pada CV. Jaya Motor di Lampung Selatan". Diperoleh $r_{x y}$ hitung $=0,962$, perbandingan menunjukkan $r_{x y}$ hitung $=0,962>r_{x y}$ tabel $=0,381$. Hasil perhitungan Koefisien Penentu sebesar 92,5444 \% ini menunjukkan bahwa koordinasi pada CV. Jaya Motor di Lampung Selatan berhubungan dengan prestasi kerja. Nilai $t_{\text {hitung }}$ dan $t_{\text {tabel }}$ adalah $t_{\text {hitung }}=17,62>t_{\text {tabel }}=$ 1,708 , ini menunjukkan bahwa ada hubungan antara pengkoordinasian dengan prestasi kerja karyawan pada CV. Jaya Motor di Lampung Selatan.
\end{abstract}

Kata kunci: Karyawan, Kerja, Koordinasi, Prestasi.

\section{PENDAHULUAN}

Persaingan dalam dunia bisnis akan semakin kompetitif dengan masuknya produk dari negara lain. Perusahaan akan semakin menyadari dengan ketinggalan teknologi, rendahnya sumber daya manusia serta modal yang kurang akan semakin mempersulit posisi untuk bersaing. Menguasai faktor-faktor produksi yang sangat penting. Tenaga manusia dalam suatu perusahaan dinamakan dengan karyawan. Melalui karyawan inilah diharapkan visi dan misi perusahaan akan dapat berharga disamping juga dibutuhkan modal yang cukup untuk menjalankan operasional perusahaan.

Untuk mengelola dana yang diinvestasikan tersebut tentunya diperlukan karyawan yang ahli dalam bidangnya. Melihat kenyataan tersebut, semakin jelas bahwa unsur manusia (karyawan) dalam suatu perusahaan atau industri merupakan ujung tombak terhadap keberhasilan perusahaan. Perusahaan tidak saja harus mengejar target dan realisasi, produksi, penjualan dan sebagainya, akan tetapi juga harus menyiapkan karyawan yang profesional untuk mengelolanya.

Peran karyawan mempunyai nilai dan mempengaruhi seluruh sistem bekerjanya organisasi kemampuan dari para karyawan juga dipengaruhi oleh lingkungan tempat bekerja, sarana dan prasarana serta hubungan interaksi antar manusia yang berada dalam organisasi tersebut. Hubungan antar manusia dalam perusahaan diimplementasikan melalui hubungan antar pimpinan dengan bawahan dan sesama bawahan. Kegiatan tersebut dilakukan melalui rapat-rapat, pertemuan-pertemuan yang bertujuan untuk memberikan kesepahaman kerja, agar tujuan dan sasaran perusahaan dapat dicapai. Kegiatan tersebut 
merupakan salah satu bentuk pelaksanaan koordinasi yang harus terus dilakukan sehingga melalui koordinasi yang baik, maka akan dapat diketahui keinginan pimpinan dan juga keinginan karyawan.

Koordinasi adalah kegiatan mengarahkan, mengintegrasikan dan mengkoordinasikan unsur-unsur manajemen (6 M) dan pekerjaan-pekerjaan para bawahan dalam mencapai tujuan organisasi (Hasibuan, 2005). Menurut Soewarno Handayaningrat, 2007:90), bahwa koordinasi adalah pencapaian usaha kelompok secara teratur dan kesatuan tindakan dalam mencapai tujuan bersama. Dilihat dari pengertian tersebut di atas maka melalui koordinasi akan dapat dicapai kesatuan tindakan untuk mencapai tujuan yang diinginkan secara bersama-sama. Mengadakan koordinasi antar elemen yang ada dalam perusahaan akan dapat memperkecil kemungkinan terjadinya ketimpangan dan penyimpangan dalam melakukan pekerjaan. Dengan melakukan koordinasi secara rutinitas akan dapat menumbuhkan rasa loyalitas, disiplin kerja, prestasi kerja, produktivitas kerja, semangat kerja dan sebagainya.

Koordinasi yang telah dilaksanakan oleh CV. Jaya Motor dalam bentuk pertemuan-pertemuan dan rapat-rapat yang dilakukan 2 bulan sekali. Melalui rapat dan pertemuan tersebut seluruh karyawan diundang untuk hadir selanjutnya pimpinan perusahaan maupun pihak-pihak yang berkompeten memberikan pengarahan baik mengenai adanya kebijaksanaan baru dari perusahaan maupun menyangkut kinerja karyawan serta kendala-kendala yang dihadapi di lapangan. Pada kesempatan tersebut pula biasanya pihak perusahaan akan memberikan jalan keluarnya terhadap kendala yang dihadapi karyawan.

Melakukan penilaian prestasi kerja karyawan mutlak harus dilakukan untuk melihat perkembangan kerja karyawan secara keseluruhan. Hal tersebut dilakukan sejak karyawan diterima kemudian ditempatkan pada pekerjaannya, maka sejak itu pula pimpinan mulai melakukan penilaian terhadap karyawan tersebut. Penilaian prestasi kerja menurut Andrew F. Sikula merupakan evaluasi yang sistematis terhadap pekerjaan yang telah dilakukan oleh karyawan dan ditunjukan untuk pengembangan (Hasibuan, 2005).

Dengan demikian penilaian prestasi kerja ini pada dasarnya merupakan suatu proses mengestimasi dan menentukan nilai keberhasilan pelaksanaan tugas para karyawan CV. Jaya Motor sebagai salah satu perusahaan dagang yang menjual kendaraan bermotor roda dua dengan merek Yamaha seperti Jupiter Z, Yamaha Vixion, Yamaha Mio, Vega RR dan berbagai tipe yang lain. Perusahaan telah pula melakukan fungsi-fungsi manajemen (Perencanaan, Pengorganisasian, Pelaksanaan dan Pengawasan dalam mengarahkan karyawan. Melalui pengkoordinasian yang dilakukan oleh pimpinan diharapkan dapat mendorong prestasi kerja karyawan dalam berbagai bidang, terutama dalam mengejar target dan realisasi penjualan kendaraan.

Frekuensi koordinasi yang masih kurang sehingga menimbulkan ketimpangan antara keinginan perusahaan dan keinginan karyawan. Berdasarkan uraian tersebut di atas, maka penulis tertarik untuk meneliti lebih lanjut dengan judul: "Hubungan Pengkoordinasian dengan Prestasi Kerja Karyawan Pada CV. Jaya Motor di Lampung Selatan".

\section{KAJIAN TEORI}

\section{Pengertian Manajemen Sumber Daya Manusia}

Menurut T Hani Handoko (2009) bahwa, Manajemen Sumber Daya Manusia merupakan penarikan, seleksi, pengembangan, pemeliharaan dan penggunaan sumber daya manusia untuk 
mencapai tujuan individu dan tujuan organisasi.

Menurut M. Manullang (2008), Manajemen Sumber Daya Manusia adalah seni dan ilmu memperoleh, memajukan dan manfaatkan tenaga kerja sehingga tujuan organisasi dapat direalisir secara dayaguna sekaligus adanya kegairahan bekerja dari para pekerja.

Sedangkan menurut Malayu SP. Hasibuan (2005), bahwa, Manajemen Personalia adalah Ilmu dan seni mengatur hubungan dan peranan tenaga kerja agar efektif dan efisien membantu terwujudnya tujuan perusahaan, karyawan dan masyarakat.

Dari beberapa definisi tersebut di atas, maka dapat dikatakan bahwa, Manajemen Sumber Daya Manusia adalah ilmu dan seni yang berkenaan dengan proses penarikan, penggunaan dan pembinaan tenaga kerja sehingga efektifitas dan efisiensi dapat dicapai semaksimal mungkin dalam pencapaian suatu tujuan. Keberhasilan pengelolaan organisasi atu perusahaan ditentukan oleh kegiatan pemberdayaan sumber daya manusia secara menyeluruh.

\section{Fungsi-Fungsi Manajemen Sumber Daya Manusia}

Pelaksanaan fungsi-fungsi Manajemen Sumber Daya Manusia dengan baik dalam suatu organisasi atau perusahaan berarti telah melaksanakan upaya memberdayakan sumber daya manusia sesuai dengan tujuan yang telah ditetapkan perusahaan. Dalam rangka mencapai tujuan yang telah ditetapkan oleh perusahaan, maka seorang manajer personalia perlu melaksanakan berbagai fungsi dari Manajemen Sumber Daya Manusia. Menurut SP. Hasibuan (2005), Fungsi-fungsi tersebut adalah sebagai berikut :

a. Perencanaan (human resources planning) merupakan perencanaan tenaga kerja yang sesuai dengan kebutuhan perusahaan secara efektif dan efisien guna menentukan terwujudnya tujuan perusahaan.

b. Pengorganisasian adalah kegiatan untuk mengorganisasikan semua karyawan dengan menetapkan pembagian kerja, hubungan kerja, pendelegasian wewenang, integrasi dan koordinasi dalam organisasi.

c. Pengarahan adalah kegiatan mengarahkan semua karyawan, agar mau bekerjasama, bekerja efektif dan efisien dalam membantu tercapainya tujuan perusahaan, karyawan dan masyarakat.

d. Pengendalian (controlling) adalah kegiatan mengendalikan semua karyawan agar mentaati peraturan perusahaan dan bekerja sesuai dengan rencana.

e. Pengadaan (recrutment) adalah proses penarikan, seleksi, penempatan, orientasi dan indikasi untuk mendapatkan karyawan yang sesuai dengan kebutuhan perusahaan.

f. Pengembangan (development) adalah proses meningkatan keterampilan teknis, teoritis konseptual dan moral karyawan melalui pendidikan dan pelatihan. Pendidikan dan pelatihan yang diberikan harus sesuai dengan kebutuhan pekerjaan sekarang maupun masa depan.

g. Kompensasi (compensensation) adalah pemberian balas jasa langsung (direct) dan tidak langsung (inderect) dalam bentuk uang maupun barang kepada karyawan sebagai imbalan jasa yang diberikannya kepada perusahaan.

h. Pengintegrasian (integration) adalah kegiatan untuk mempersatukan kepentingan perusahaan dan kebutuhan karyawan, agar terciptanya kerjasama yang serasi dan menguntungkan.

i. Pemeliharaan (maintenace) adalah kegiatan untuk memelihara atau meningkatkan kondisi fisik, mental dan loyalitas karyawan agar mereka tetap bekerjasama sampai pensiun. 
j. Kedisiplinan merupakan fungsi Manajemen Sumber Daya Manusia yang terpenting dan kunci terwujudnya karena tanpa disiplin yang baik, sulit untuk terwujudnya tujuan secara maksimal.

k. Pemberhentian (separation) adalah putusnya hubungan kerja seorang dari suatu perusahaan.

\section{Pengertian Koordinasi}

Menurut GR. Terry yang dikutip oleh Malayu SP. Hasibuan, (2005), menyatakan bahwa koordinasi adalah suatu usaha yang sinkron dan teratur untuk menyediakan jumlah dan waktu yang tepat dan mengarahkan pelaksanaan untu menghasilkan suatu tindakan yang seragam dan harmonis pada sasaran yang telah ditentukan. Sedangkan menurut Malayu SP. Hasibuan (2005), koordinasi adalah kegiatan mengarahkan, mengintegrasikan, dan mengkoordinasikan unsur-unsur manajemen $(6 \mathrm{M})$ dan pekerjaan-pekerjaan para bawahan dalam mencapai tujuan organisasi.

Menurut JD. Mooney dan Alan D. Reiley yang dikutip oleh Soewarno Handayaningrat (2009), menyatakan bahwa koordinasi adalah pencapaian usaha kelompok secara teratur dan kesatuan tindakan di dalam mencapai tujuan bersama. Berdasarkan berbagai pendapat ahli tersebut di atas sebenarnya dapat dipakai satu istilah koordinasi yaitu keselarasan. Keselarasan disini dimaksudkan sebagai kesatuan tindakan, usaha menyesuaikan antar bagian maupun keseimbangan antar satuan dengan sasaran keselarasan.

\section{Hubungan Koordinasi Terhadap Prestasi Kerja Karyawan}

Koordinasi sebagai upaya pimpinan dalam mengintegrasikan segala kegiatan dalam perusahaan akan sangat berguna bagi karyawan dalam melaksanakan pekerjaan yang dibebankan kepadanya. Karyawan akan memberikan segala daya dan upayanya untuk memberikan hasil kerja terbaik manakala terjalin adanya hubungan yang harmonis antara pimpinan dan bawahan.

Melalui koordinasi diharapkan prestasi kerja karyawan akan dapat ditingkatkan karena melalui koordinasi ini akan terjalin adanya mitra kerja yang kondusif. Prestasi kerja adalah keadaan seseorang dapat menyelesaikan pekerjaan yang dibebankannya dengan tingkat pendidikan dan keterampilan yang dimilikinya.

Kepuasan kerja merupakan salah satu faktor dalam setiap dalam kerja, karena dapat berfungsi menimbulkan atau meningkatkan semangat kerja (motivasi), sehingga karyawan akan bekerja lebih baik (prestasi kerja). Tidak adanya kepuasan kerja pada karyawan akan bekerja lebih baik (prestasi kerja).

Tidak adanya kepuasan kera pada karyawan dapat menjadikan ia cepat bosan, emosinya tidak stabil, sering melamun dan melakukan kesibukan yang tidak ada hubungannya dengan pekerjaan yang seharusnya ia lakukan. Akibat yang lebih buruk lagi dari tidak adanya kepuasaan kerja, karyawan akan semakin menurun.

\section{METODE PENELITIAN}

\section{Objek Penelitian}

Penelitian ini dilaksanakan pada CV. Jaya Motor yang beralamat di Jalan Sidomulyo No. 45 Kecamatan Katibung Lampung Selatan. Perusahaan ini bergerak dalam bidang perdagangan yaitu menjual kendaraan bermotor roda dua merek Yamaha. Penelitian dilaksanakan pada bulan Februari sampai dengan April 2017. 
Metode dan Teknik Pengumpulan Data

Dalam penelitian ini jenis data yang diperlakukan adalah :

a. Data Primer

Data primer merupakan data dasar yang akan diperoleh langsung tanpa perantara orang atau lembaga lain sebagai pihak ketiga. Data primer ini diperoleh dengan wawancara melalui responden dengan menggunakan daftar pertanyaan.

\section{b. Data Sekunder}

Data skunder merupakan data yang diperoleh melalui orang lain yang berhubungan dengan permasalahan yang dipecahkan. Data sekunder ini diperoleh melalui cara studi dokumenter yaitu mengumpulkan dan mempelajari brosurbrosur serta dokumen organisasi.

Langkah-langkah pengumpulan data yang penulis lakukan dengan mengadakan penelitian lapangan yaitu Penelitian yang dilakukan di CV. Jaya Motor, adapun teknik yang digunakan dalam pengumpulan data adalah dengan :

1. Observasi, yaitu mengadakan survey atau pengamatan langsung kelokasi penelitian.

2. Interview atau wawancara, yaitu mengadakan tanya jawab langsung dengan karyawan pada CV. Jaya Motor.

3. Dokumentasi, yaitu mengumpulkan dan mencatat dokumentasi yang relevan.

4. Kuisioner, yaitu membuat pertanyaan yang berhubungan dengan variabel penelitian.

\section{Sampel dan Populasi}

Populasi menurut Winarno (2001) adalah "Keseluruhan objek atau keseluruhan individu yang akan diteliti". Dalam penelitian ini keseluruhan jumlah karyawan yang ada pada CV. Jaya Motor di
Lampung Selatan sebanyak 27 orang karyawan. Suharsimi Arikunto (2007) menyatakan bahwa apabila subyek kurang dari 100 lebih baik diambil semua sehingga penelitiannya merupakan penelitian populasi, selanjutnya jika subyeknya lebih dari 100 dapat diambil sampel antara 10\% $15 \%$ atau $20 \%$ - 25\%. Berdasarkan pendapat tersebut di atas, maka penulis menentukan sampel jumlah sebanyak 27 orang karyawan.

\section{Metode Analisis Data}

Analisis kualitatif, yaitu menganalisis permasalahan dengan cara membandingkan antara teori dengan permasalahan yang dihadapi oleh CV. Jaya Motor di Lampung Selatan yaitu mengenai koordinasi dan prestasi kerja.

Analisis kuantitatif, yaitu menganalisis hubungan dengan menggunakan metode statistik, dimana data-data yang diperoleh dari lapangan, kemudian ditabulasikan dalam bentuk angka-angka, seterusnya dianalisis dengan menggunakan rumus Korelasi Product Moment. Dimana rumusnya sebagai berikut :

$$
r_{x y}=\frac{N \sum X_{i} Y-\left(\sum X_{i}\right)\left(\sum Y_{i}\right)}{\sqrt{\left\{N \sum X_{i}{ }^{2}-\left(\sum X_{i}\right)^{2}\right\}\left\{N \sum Y_{i}^{2}-\left(\sum Y_{i}\right)^{2}\right\}}}
$$

Keterangan:

$$
\begin{aligned}
& \mathrm{r}_{\mathrm{xy}}=\text { Koefisieni korelasi } \\
& \mathrm{X}=\text { Variabel koordinasi } \\
& \mathrm{Y}=\text { Variabel prestasi kerja } \\
& \mathrm{N}=\text { Jumlah populasi }
\end{aligned}
$$

Untuk mengetahui besarnya pengaruh, penghitungan koefisien korelasi tersebut kemudian dilanjutkan dengan Rumus Koefisien Determinasi atau Koefisien Penentu (KP):

$$
K P=(r)^{2} x 100 \%
$$


Untuk menguji secara hipotesis secara parsial digunakan Uji t dengan rumus :

$$
t_{\text {hitung }}=\frac{r \sqrt{N-2}}{\sqrt{1-r^{2}}}
$$

Keterangan:

$$
\begin{array}{ll}
\mathrm{t}_{\text {hitung }} & =\text { Nilai } \mathrm{t} \\
\mathrm{r} & =\text { Koefisien Korelasi } \\
\mathrm{N} & =\text { Jumlah responden }
\end{array}
$$

Kriteria untuk Uji $\mathrm{t}$ adalah sebagai berikut :

a) Jika $t_{\text {hitung }}>t_{\text {tabel }}$ maka Ha diterima dan Ho ditolak.

b) Jika $t_{\text {hitung }} \leq \mathrm{t}_{\text {tabel }}$ maka Ha ditolak dan Ho diterima.

\section{HASIL DAN PEMBAHASAN}

\section{Analisis Kualitatif}

Untuk mengetahui pengaruh koordinasi dalam meningkatkan prestasi kerja karyawan pada CV. Jaya Motor, maka digunakan alat analisis kualitatif dan kuantitatif. Pada analisis kualitatif ini penulis akan menganalisis berdasarkan teori-teori yang berkaitan dengan koordinasi dan juga prestasi kerja. Dengan didasarkan atas teori tersebut, maka langkah selanjutnya adalah membuat daftar pertanyaan/kuisioner yang akan disebarkan kepada 27 orang sebagai responden penelitian.

Setiap alternatif jawaban yang diberikan tersebut akan diberi skor dengan ketentuan sebagai berikut:
a. Apabila alternatif jawaban A, maka diberi skor 3.
b. Apabila alternatif jawaban B, maka diberi skor 2.
c. Apabila alternatif jawaban $\mathrm{C}$, diberi skor 1.

Dengan demikian jumlah skor maksimal dan minimal dari 10 item pertanyaan adalah 10 sampai dengan 30, yang dibagi dalam kategori:

a. Sangat baik/Tinggi dengan skor antara 23 sampai dengan 30

b. Baik/Sedang dengan skor antara 16 sampai dengan 22

c. Kurang/Rendah dengan skor antara 10 sampai dengan 15

Berdasarkan hasil rekapitulasi jawaban kuisioner dari 27 orang responden (lampiran 6) diperoleh hasil sebagai berikut : 17 orang responden $(62,96 \%)$ menjawab koordinasi sangat baik, 7 orang responden $(25,93 \%)$ menjawab koordinasi baik dan 3 orang responden $(11,11 \%)$ menjawab koordinasi kurang baik.

Sedangkan yang berkaitan dengan prestasi kerja diperoleh hasil : 16 orang responden $(59,26 \%)$ menjawab prestasi kerja sangat meningkat, 3 orang responden $(11,11 \%)$ menjawab prestasi kerja meningkat dan 8 orang responden $(29,63$ $\%)$ menjawab prestasi kerja menurun. Dari hasil jawaban kuisioner tersebut di atas akan direkapitulasi pada Tabel 1.

Tabel 1. Rekapitulasi Jawaban Hasil Kuisioner dari 27 orang Responden pada CV Jaya Motor

\begin{tabular}{lccc}
\hline \multirow{2}{*}{ Keterangan } & \multicolumn{3}{c}{ Kriteria } \\
\cline { 2 - 4 } & $\begin{array}{c}\text { Sangat } \\
\text { baik }\end{array}$ & Baik & Kurang \\
\hline $\begin{array}{l}\text { Koordinasi } \\
\begin{array}{l}\text { Prestasi } \\
\text { Kerja }\end{array}\end{array}$ & $62,96 \%$ & $5,93 \%$ & $11,11 \%$ \\
\hline \multicolumn{1}{c}{ Rata-rata } & $61,11 \%$ & $11,11 \%$ & $29,63 \%$ \\
\hline
\end{tabular}

Tabel 1. menunjukkan bahwa rata-rata jawaban responden dari kuisioner yang berkaitan dengan koordinasi maupun prestasi kerja diperoleh hasil : rata-rata $61,11 \%$ responden menyatakan sangat baik, $\quad 1852 \%$ menyatakan baik dan 20,37 \% menyatakan kurang. Berdasarkan analisis kualitatif tersebut, maka dapat diketahui bahwa ada hubungan 
pengkoordinasian dengan prestasi karyawan pada CV. Jaya Motor di Lampung Selatan.

\section{Analisis Kuantitatif}

Setelah dianalisis menggunakan analisis kualitatif, maka penulis juga akan menganalisis dengan menggunakan data kuantitatif. Data kuantitatif ini diperoleh dari mentabulasikan hasil kuisioner yang penulis sebarkan kepada 27 orang responden dalam bentuk angka-angka sesuai dengan skor jawaban yang telah dijelaskan pada bab sebelumnya.

Dari hasil tabulasi dalam bentuk angkaangka tersebut sebagaimana terlampir pada lampiran 3 dan 4, kemudian penulis oleh melalui rumus statistik yaitu Product Moment, sehingga dapat dilihat hubungan antara variabel koordinasi (X), maupun yang berhubungan prestasi kerja (Y). Berdasarkan rekapitulasi hasil kuisioner diperoleh :

\begin{tabular}{|c|c|c|}
\hline $\mathrm{N}$ & $=27$ & $\sum \mathrm{X}^{2}$ \\
\hline$\sum X$ & $=668$ & $\sum \mathrm{Y}^{2}$ \\
\hline$\sum \mathrm{Y}$ & $=647$ & $\sum X Y$ \\
\hline
\end{tabular}

Setelah diketahui $r_{x y}$ hitung $=0,962$, maka setelah dibandingkan nilai $\quad r_{x y}$ tabel product moment pada $\mathrm{n}=27$ pada taraf signifikan $5 \%=0,381$ maupun pada taraf signifikan $1 \%=0,487$ perbandingan tersebut menunjukkan $r_{\text {hitung }}=0,962>r_{\text {tabel }}$ taraf signifikan $5 \%=0,381$ dan $1 \%=$ 0,487. Kemudian dibandingkan pula dengan standar pengukuran korelasi ternyata $r_{x y \text { hitung }}=0,962$ terletak antara $0,810-1,000$ dengan kriteria sangat tinggi.

Berdasarkan hasil perhitungan tersebut di atas, maka penulis menyimpulkan bahwa hipotesis yang menyatakan bahwa "Ada hubungan pengkoordinasian dengan prestasi kerja karyawan pada CV. Jaya Motor di Lampung Selatan" terbukti kebenarannya.

Untuk mengetahui kadar prosentase pengaruh koordinasi dengan prestasi karja karyawan pada CV. Jaya Motor, maka penulis akan menggunakan rumus Koefisien Penentu (KP) adalah KP $=r^{2} \mathrm{x}$ $100 \%$. Nilai $r_{\text {hitung }}=\mathbf{0 , 9 6 2}$ yang diperoleh dari hasil perhitungan sebelumnya. Hasil perhitungan Koefisien Penentu tersebut menunjukkan bahwa 92,5444 \% koordinasi berpengaruh terhadap prestasi kerja karyawan, sementara faktor lain hanya $7,4556 \%$.

Untuk mengetahui kebenaran hipotesis yang telah penulis kemukakan, maka berikut ini akan penulis sajikan uji hipotesis. Uji hipotesis ini ditujukan untuk mengukur tingkat kevalidan dari hasil perhitungan sebelumnya. Nilai $t$ hitung diperoleh sebesar $=17,62$ pada $\mathrm{N}=27$. setelah nilai tersebut dibandingkan dengan nilai $t$ tabel dengan menggunakan derajat kebebasan $(d b) \mathrm{N}-2$, tingkat signifikan $(\alpha$ $=5 \%$ ) diperoleh hasil $t$ hitung lebih besar dari pada $t_{\text {tabel }}$ yaitu : $t_{\text {hitung }}=17,62>\mathrm{t}_{0,05}$ $(\mathrm{N}-2)=1,708$. Dengan demikian dapat disimpulkan bahwa, hipotesis yang sebelumnya penulis ajukan, yaitu "Ada Hubungan Pengkoordinasian dengan Prestasi Kerja Karyawan pada CV. Jaya Motor di Lampung Selatan", dapat diterima.

\section{KESIMPULAN DAN SARAN}

\section{Kesimpulan}

Berdasarkan hasil penelitian diperoleh simpulan bahwa hasil rekapitulasi jawaban kuisioner dari 27 orang responden diperoleh hasil sebagai berikut : 17 orang responden $(62,96 \%)$ menjawab koordinasi sangat baik, 7 orang responden $(25,93 \%)$ menjawab koordinasi baik dan 3 orang responden $(11,11 \%)$ menjawab koordinasi kurang baik. Hasil kuisioner tentang prestasi kerja diperoleh hasil : 16 orang responden $(59,26 \%)$ menjawab prestasi kerja sangat meningkat, 3 orang responden $(29,63 \%)$ menjawab prestasi kerja 
menurun. Diketahui $r_{x y}$ hitung $=0,962$, perbandingan tersebut menunjukkan $r$ xy hitung $=0,962>r_{x y}=0,487$. Hasil perhitungan Koefisien Penentu sebesar $92,5444 \%$ ini menunjukkan bahwa pengkoordinasian pada CV. Jaya Motor di Lampung Selatan berhubungan dengan prestasi kerja. Uji $t$ hitung dibandingkan dengan nilai $t$ tabel diperoleh hasil $t$ hitung lebih besar daripada $t$ tabel yaitu : $t$ hitung $=$ $17,62>t_{0,05}(n-2)=1,708$. Dengan demikian dapat disimpulkan bahwa, hipotesis yang sebelumnya ajukan, yaitu "Ada Hubungan Pengkoordinasian dengan Prestasi Kerja Karyawan pada CV. Jaya Motor di Lampung Selatan”, dapat diterima.

\section{Saran}

Adapun saran yang diajukan peneliti adalah sebagai berikut:

1. Hendaknya koordinasi yang telah terjalin dengan baik antara atasan dengan bawahan terus dipertahankan, mengingat pentingnya koordinasi tersebut dalam mencapai tujuan perusahaan.

2. Frekuensi koordinasi hendaknya ditambah lagi dan dilaksanakan kepada semua karyawan sesuai dengan peraturan-peraturan.

\section{DAFTAR PUSTAKA}

Arikunto, Suharsimi. 2006. Prosedur Penelitian Suatu Pendekatan Praktek. Jakarta: Renika Cipta.

Hadi, Sutrisno. 2007. Metode Penelitian. Jakarta: Ghali Indonesia.

Handoko, T. Hani. 2009. Manajemen Sumber Daya Manusia. Jakarta: Penerbit Rineka.
Hasibuan, Malayu SP., 2005. Pengantar Manajemen. Jakarta: Bumi Aksara.

Sumber Daya Manusia. Jakarta: PT. Gramedia.

JD. Mooney, James. 2001. Konsep Pengenbangan Organisasi Publik. Bandung: Sinar Baru Algesindo.

J.S., Payaman. 2006. Pengantar Ekonomi Sumber Daya Manusia. Jakarta: LPFE Universitas Indonesia.

Manullang, M. 2005. Dasar_Dasar Manajemen. Yogyakarta: Gadjah Mada University Press.

Nitisemito, Alex S. 2005. Manajemen Personalia. Jakarta: Ghalia Indonesia.

Ranupandojo, Heidjrachman. 2008. Teori dan Konsep Manajemen. Yogyakarta: Penerbit Fakultas Ekonomi Universitas Gajah Mada.

Ruky, A. S. 2007. Sistem dan Administrasi Pengkajian untuk Perusahaan di Indonesia. Jakarta: BPFE Universitas Indonesia.

Sudjana. 2003. Metode Statisfik I dan II. Yogyakarta: Penerbit FP UGM. 